\title{
The Mining Education Cluster
}

\section{Natalia Anatolyevna Kazachek ${ }^{1}$}

\author{
Julia Sergeevna Tokareva² \\ ${ }^{1}$ Transbaikal State University, Chita, Russian Federation \\ Email: kazachekna@mail.ru \\ 2Transbaikal State University, Chita, Russian Federation
}

Doi:10.5901/mjss.2015.v6n5s4p205

\begin{abstract}
The isolated activity of the government authorities, business and education system in the modern rapidly developing world does not lead at least to the progress. The innovative forms of progressive interaction are required. Such forms include clusters and, in particular, the education clusters. The article presents the material on the creation of the mining education cluster in the case of the Zabaikalsky Krai. The cluster formation is based on the public-private partnership. The cluster activity will provide for the development of the innovative and entrepreneurial culture, and will contribute to the establishment of small innovative enterprises. The paper lists the basic prerequisites for the formation of the mining education cluster in the region, as well as the functions implemented within the framework of the new cluster. It proposes the results of modelling the structure and status of the mining education cluster by means of the mathematical apparatus of the theory of sets. The consideration is given to the indicators of the cluster operation obtained due to the merger of organizations. The presented formal description of the cluster allows us to predict the expected scope of the cluster, its optimized structure, the possibilities of its development, and the assessment of the efficiency of various mechanisms of coordination and decision-making of the cluster participants. The model of the mining education cluster reflects the basic regularities of its functioning, the process of changing its structure, and the cluster-generating ties.
\end{abstract}

Keywords: cluster, education cluster, scientific and education cluster, mining education cluster, mining industry, public private partnership.

\section{Introduction}

The organizations of the Zabaikalsky Krai are becoming more aware of the lack of their own innovation potential, which includes the shortage of qualified personnel, the lack of their own scientific and research resource base, the experience in the establishment of experimental platforms, etc. (Afonin, 2010).

A cluster is an innovative form of partnership that allows us to solve the above-mentioned problems. It is believed that the idea of creating clusters belongs to Michael Porter, a Nobel laureate, who produced the following definition: "a cluster or an industrial group is a group of neighboring interconnected companies and organizations associated therewith that operate in a particular sphere, are characterized by the common activities, and are complementary to each other" (Porter, 2002).

Quite a number of works is devoted to the study of various aspects of the cluster formation. The works (Porter, 2003; Denison, 1985; Enright, 1996; Veblen, 1964) examine the contemporary status of the problem of modelling the internal and external environment of an innovative cluster, and the work (Rosenfeld, 1997) studies the problems of formation and development of the clusters of enterprises at the regional level. A number of studies (Porter, 1993; Tsikhan, 2003) are devoted to the activity aimed at supporting clusters, which contributes to the effective and mutually beneficial cooperation of subjects of the production process. The works (Marceau, 1999; Enright, 2000; OESD Reviews of Regional Innovation, 2007) provide several comparisons of the structures of various clusters.

Gromyko (2007) noted that the fundamental practice-oriented science played an important role in the creation of Russian clusters.

In March 2012, the Ministry of Economic Development of the Russian Federation announced a contest of innovative clusters ("The Announcement on the Formation of the List of Pilot Programs for the Development of Innovative Regional Clusters"). In August 2012, a list of the innovative regional clusters was approved by the Government of the Russian Federation ("The List of Innovative Regional Clusters"). The list included 25 clusters, with respect to which the 
Ministry of Economic Development of Russia was tasked to produce the government support measures.

In recent years, the education and scientific-education clusters have been actively created in Russia ("The Tambov Business College"; "The Ural State University of Economics"; "The Scientific and Education Cluster in the Sphere of Trade, Hospitality Industry, and Services in the Republic of Tatarstan").

A scientific-education or education cluster is considered as a territory of development based on a large education center and high-tech companies that rely on the scientific and human potential of the region and the close cooperation with the industry.

The driving forces of the scientific cooperation between the participants of the education cluster are the joint scientific-research, design-experimental, and innovative-technological projects. It is within the framework of these projects that such partnership structures as training and research centers, certification centers, assessment centers, technology parks, etc. are being established and currently operating.

For example, at the Moscow Institute of Physics and Technology, two scientific and education clusters are established: Phystech XXI and the IT-cluster ("Phystech-Soiuz"; "The Moscow Institute of Physics and Technology"). The key elements of the clusters are as follows: the world-class university, the research infrastructure surrounding the university, the zone of high-tech companies and start-ups, the comfortable urban environment on the territory of the cluster, the central boarding school Phystech-Lyceum and the system of Phystech-schools, the established system of search and preparation of the technological leaders, and the system for controlling the clusters and the university.

The educational clusters are to be established in the absence of the state program for creation of educational clusters and any methodological recommendations of the Ministry of Education and Science of the Russian Federation.

In late 2014, the article "The Navigator of Education Clusters: from a Schoolboy to an Employer" was published, which described the forthcoming steps for increasing the competitiveness of education clusters. In 2015, the formation of regular rankings for the education clusters will take place, and the multimedia geo-informational system "The Navigator of Education Clusters" will be created ("The Navigator of Education Clusters: from a Schoolboy to an Employer").

The education clusters are divided into two major groups: the intraregional group (in the center, there are higher education organizations, scientific and research institutes, design-experimental bureaus that work directly with the employer enterprises) and the interregional group (due to the consolidated efforts, they can be implemented in the neighboring regions of the Russian Federation). The priority sectors are distinguished for the creation of clusters. These sectors include the nuclear power generation industry, the aviation and space industry, the mineral industry, the metallurgy, the nanotechnology industry, etc.

The Ministry of Education and Science of the Russian Federation has defined the methodology for calculating the main indicators and their benchmarking used in the framework of the instrument of information support for the generation and development of innovations that enhance the competitiveness of education clusters ("The Methodology for Calculating the Main Indicators and their Benchmarking Used in the Framework of the Instrument of Information Support for the Generation and Development of Innovations that Enhance the Competitiveness of Education Clusters"). The results of the approbation research are publicly presented ("Rankings of Education Clusters: the Main Results of the Analysis and Interpretation of the Data Obtained in the Framework of the Approbation Research").

According to the published rankings of the interregional and regional education clusters, in the Siberian Federal District, seven education clusters have been established, but at the same, none of them is in the Zabaikalsky Krai. There are also no education clusters in the neighboring regions of the Far Eastern Federal District ("Ranking of the Interregional Education Clusters"; "Ranking of the Regional Education Clusters").

It seems expedient to establish in the Zabaikalsky Krai based on the public-private partnership education clusters combining the educational, scientific-technical, and production functions. The cluster activity must develop the innovative and entrepreneurial culture, and contribute to the establishment of small innovative enterprises.

The conditions of long-term partnership being established in this region between the Transbaikal State University, the regional authorities, and the mining industry corporations are capable of ensuring the formation of the education cluster for one of the priority sectors defined by the Government of the Russian Federation. The benchmark for establishing the education clusters is the transition of the region to the new techno-industrial and sociocultural structure.

The paper lists the basic prerequisites for the formation of the mining education cluster in the region, as well as the functions implemented within the framework of the new cluster. It proposes the results of modelling the structure and status of the mining education cluster by means of the mathematical apparatus of the theory of sets. The consideration is given to the indicators of the cluster operation obtained due to the merger of organizations. 


\section{The Prerequisites for Establishing a Cluster in the Region}

The main mechanism for the formation of effective education clusters is to identify the actual problems of the region development, and to solve them later on the project basis, which provides for the interaction of education, employers, and the government on the issues concerning the implementation and legitimation of these solutions.

The Zabaikalsky Krai has great potential for establishing an education cluster in the mining industry. The basic prerequisites for the formation of the mining education cluster are as follows:

1. The establishment of the electrotechnical industrial center based on the Udokan copper deposit development. The development of the unique in its reserves Udokan copper deposit could be the basis for the formation of a large innovative industrial center for the production of electric machines of various applications, electrotechnical equipment, and gears. This primarily involves the formation of the necessary railway and electrical power infrastructures, and relies on the well-developed structure of the generating capacity in the region and on the performance capabilities of the Trans-Siberian Railway. The Udokan deposit development must be accompanied by the establishment of the mining-and-metallurgical integrated works, the products of which (from a copper concentrate to the mix of copper products) can find its place in the growing global market for copper. It is also required to start the metallurgical productions of the second priority that manufacture special and precision copper-based alloys. At the same time, the foundation for economic growth in the region should be presented not by the raw manufacture, but by the based on the raw material base high-tech manufacture of the products with high added value. Such manufacture includes electric machines (motors, generators, transformers, and their parts and components) and electrotechnical copper-containing equipment. Moreover, based on such line productions and manufacturing of special precision alloys, it is possible to develop a network of small science-intensive innovative enterprises that will produce under special orders high-tech measuring equipment and a wide range of devices even using the cuprate superconducting elements of the $2^{\text {nd }}$ generation.

2. The creation of the cluster of zeolite productions based on the natural zeolites deposit. The infrastructure project on the development of one of the most unique in its resources deposit of zeolites involves the establishment of a system of various productions engaged in manufacturing the high-tech commodity products made from zeolites with the possibility of continuous extension of the list of productions in accordance with the creation of the new ways for the useful applications of zeolites. The implementation of the project necessitates restoring and completing the construction of the part of the required transport and energy infrastructure.

3. The construction of the coal chemistry productions based on the Transbaikal coals. The project involves the development of the regional coal deposits by means of the transition to the catalyst deep processing of coal based on the CTL technologies of different types. The foundation of the commodity products produced from the low-energy coal should be the main components of the organic synthesis-the syngas, benzene, toluene, xylene, and methanol. The project involves an open architecture of the coal chemistry industrial center, which, based on the emergence of the new technologies for the production of commodity chemicals, must constantly expand the range of products due to the emergence of the new productions in the region.

\section{Modelling the Structure and Status of the Cluster}

Having serious prerequisites for the establishment of the mining education cluster, we will model the structure and status of the cluster. The convenient instrument for the formal description of the mining education cluster as a system is the mathematical apparatus of the theory of sets (Mesarovich and Takakhara, 1978).

Let us assume that:

$N(t)$ is a set of organizations associated with the mining industry in the Zabaikalsky Krai at a certain moment of time $t$.

$N_{k}(t)$ is a set of organizations included into the mining education cluster of the region at a certain moment of time $t$ $\left(N_{K}(t) \subset N(t)\right)$.

$|N(t)|$ is the set potency $N(t)$, which characterizes the total number of organizations in the region.

$\left|N_{K}(t)\right|$ is the set potency $N_{K}(t)$, which characterizes the number of organizations included into the education cluster of the mining industry in the region.

The scale and the size of the cluster will be determined by the following ratio: 


$$
\lambda=\frac{\left|N_{K}(t)\right|}{|N(t)|} .
$$

As of today, the Transbaikal State University cooperates with 12 enterprises in the region, which are to a certain extent related to the mining industry. Given that to date, in the Zabaikalsky Krai, the mining industry has 97 operating organizations according to the data provided by the Federal Agency for Subsoil Use of the Russian Federation, including the government authorities and education institutions of the higher and secondary professional training that provide training of personnel for this industry, the expected scale of the cluster at the initial stage equals to ${ }^{\lambda=\frac{13}{97}=0.134}$. Thus, the newly established association will include no less than $13 \%$ of the mining enterprises in the region. This is a good impetus for the development of the mining education cluster in the initial stage of its functioning and the meaningful indicator for the region.

A characteristic feature of any system (both of the region as a whole and of an individual cluster) is the possibility of its development. As a result, in the Zabaikalsky Krai, the new organizations can be established and the old oneseliminated. Similarly, the participants can leave the cluster or enter it. Thus, there occurs a change in the structure of the system elements and the relations between them.

The change in the structure of sets $N$ and $N_{K}$ can be carried out immediately or during a certain fixed interval of time. The immediate change in the structure of sets in this case is of no interest (Moiseev and Zaidullin, 2003). Let us assume that $P(t)$ is the set of eliminated organizations, and $Q(t)$ is the set of newly established organizations in the region for the fixed interval of time; $L(t)$ is the set of organizations that are no longer the participants of the mining education cluster, and $M(t)$ is the set of organizations that have just become the new participants of the cluster for the fixed interval of time. Then the dynamics of sets can be determined by the following laws (Pon'kina and Lobova, 2011):

$$
\begin{aligned}
& N(t)=N(t-1) \mid P(t) \cup Q(t), \\
& N_{K}(t)=N_{K}(t-1) \mid L(t) \cup M(t), \\
& \text { where } P(t) \subset N(t-1), \quad L(t) \subset N_{K}(t-1), \quad M(t) \subset N(t) .
\end{aligned}
$$

Let us assume that $n_{1}, n_{2}, \ldots, n_{m}$ are the organizations included into the mining education cluster of the region (the cluster participants), where $m=\left|N_{k}(t)\right|$. Let us individually consider indicators of the cluster operation, which were obtained due to the merge of the organizations.

Let $x_{i}(t)=\left\{x^{i}{ }_{n_{1}}(t), x^{i}{ }_{n_{2}}(t), \ldots, x^{i}{ }_{n_{m}}(t)\right\}$ be the set of managerial decisions of the education cluster participants aimed at improvement of the $i$ indicator. An analysis of the problems and prospects of the development for 10-15 years, the formation of topics for the priority research papers, a list of the required specializations, the forecast of staffing requirements for the whole region, and other directions of work of the cluster participants reveal the necessity for taking a number of decisions: the launch of programs for supporting the establishment of the cluster with the involvement of methodological support; the establishment of the independent centers for assessing the qualification of specialists with the development of assessment methodologies; the establishment of assessment centers; the introduction of the new technologies, etc.

Let $y(t)=\left\{y_{1}(t), y_{2}(t), \ldots, y_{k}(t)\right\}$ be the set of characteristics of the participants of the cluster affecting its operation (potential): the legal status of a participant, the qualification of labor force, the availability of capital, the innovations in training, the level of business activity, the experience, the availability of resources, the opportunities for research and development activities, etc. (Klepikova, 2013).

Let $z(t)=\left\{z_{l}(t), z_{2}(t), \ldots, z_{l}(t)\right\}$ be the set of conditions, on which the cluster participants cannot influence, but which they must take into account in their activities (the cluster's external factors): the legislation of the Russian Federation, the economic situation in the region and in the country in general, the policy of the regional and federal government of Russia, the cross-border position of the Zabaikalsky Krai, the demographic situation in the region, the climatic conditions, etc.

Then the synthetic indicators (aggregate or average) of the education cluster operation can be determined by the following status of the system (Klepikova, 2013):

$$
S_{k}^{i}(t)=F_{i}\left\{x_{i}(t), y(t), z(t), S_{k}(t-1)\right\},
$$

where $S_{k}^{i}(t-1)$ - is the status of the education cluster during the previous moment of time $t-1$. 


\section{Conclusion}

By the formation of the education cluster in the established conditions of the public-private partnership, a higher education institution must constantly keep in touch with the corporations, work with their specialists on different levels, search for additional funding of the developments and the implementation thereof, enlist the support of the regional government authorities, which will allow enhancing the scientific work to the new level by technologizing the processes of setting tasks, determining requirements, developing and implementing the final product. In fact, within the framework of the sustainable long-term partnership, it is required to work with the economic data of the corporation; to work with the technicians and technologies; to work with the sources of funding; and to work with the medium-term programs on the development of the corporations and the region as a whole.

Within the framework of the mining education cluster, for following functions must be implemented:

- The determination of the cluster's "core." The center of the education cluster development (cluster's secretariat) appears to be the training institution of the higher education, which will take over not only the responsibility for the educational and scientific support of the cluster, but also will act as an informational and methodological center and a communication platform, and will provide the required innovative infrastructure.

- The establishment of the legal platform of the cluster's activity. This function is provided by the development of certain legal support, which defines the roles and functions of the cluster participants and the elements of the cluster's infrastructure. The documents regulating the process of creation and functioning of the education cluster may comprise as follows: the strategies of the socioeconomic development of the subject of the Russian Federation (the strategies and concepts for development of the clusters and cluster policy); the activity plans for implementation of the strategy of socioeconomic development of the subject of the Russian Federation (the development of clusters and cluster policy); the target (state) programs on the development of economic sectors and clusters within the subject of the Russian federation (the introduction of changes to the existing industry-specific or integrated programs on the socioeconomic development of the subject of the Russian Federation); the act on the creation and development of the territorial cluster; the act on the establishment of the working group concerning the issues of the creation and development of clusters, as well as the local acts of the higher education institution, which acts as the center of the cluster development ("Education Clusters").

- The elaboration of the cluster development strategy, including the involvement of the new partners. The strategy should identify the breakthrough decisions; possess logics of roadmaps of the competitive development and of modelling the technological challenges for the global economy.

- The implementation of the continuous innovative development. The implementation of this function is possible within the framework of establishing the center of innovations, which implements the new developments, analyzes trends and prospects of the industry development.

- The provision of informational support for both the cluster operation as a whole and operation of individual subjects included therein. In order to implement this function, it is required to establish an information-based Internet resource right at the stage of the cluster designing.

- The arrangement of the youth activities, possibly in the form of a youth organization. The cluster as a social lift-a schoolchild must see himself as a student of a certain higher education institution, and then as a worker in the social or economic sphere of the region. This function must be implemented in such a way as to increase the percentage of youth employment in the scientific and production work according to the directions of the cluster operation; with the help of the young people to establish the fashion for life and work in the region, which is of particular importance in the conditions of a so called demographic "pit" and migration of talented young people to the central regions of the country.

- The establishment of the center for standardization and certification.

- The establishment of the assessment centers, which "are used to identify the potential in the sphere of human resources and establishment of the personnel reserves in the companies" (Avdeev et al., 2014).

\section{Acknowledgements}

The study was carried out within the framework of the project part of the public task in the field of scientific activity "Management of Development of the Modular Professional Training Programs for the Leading Industries of the Zabaikalsky Krai on the Basis of the Public-Private Partnership" (27.2479.2014/K). 


\section{References}

Afonin, A.S. (2010). Klaster kak integratsionnyi innovatsionnyi resurs i polius rosta regional'noi ekonomiki [The Cluster as an Innovative Integration Resource and Growth Pole of Regional Economy]. Vestnik luRGTU (NPI) - SRSTU (NPI) Bulletin, 2, 155-164 [in Russian].

Avdeev, P.B., Nikitina, L.G., Starostina, S.E., \& Dugarova, D.Ts. (2014). Otsenka rezul'tatov podgotovki spetsialistov v oblasti gornogo dela s primeneniem modul'nykh professional'nykh obrazovatel'nykh programm [Evaluation of the Results of Specialists Training in the Field of Mining Engineering with the Use of Modular Professional Training Programs]. Gornyi zhurnal - Mining Journal, 12, 110-113 [in Russian].

Denison, E. (1985). Trends in American Economic Growth, 1929-1982 (pp. 28). Washington: Brookings Institution.

Enright, M. (1996). Regional Clusters and Economic Development: A Research Agenda. Staber, U., Schaefer, N., \& Sharma, B. (Eds). Business Networks Prospects for Regional Development, 190-213. Berlin: Walter de Gruyter.

Enright, M. J. (2000). Survey on the Characterization of Regional Clusters: Initial Results. Working Paper, Institute of Economic Policy and Business Strategy: Competitiveness Program (pp. 21). University of Hong Kong.

Fiztekh-Soiuz. Retrieved from: http://phystech-union.org/project/phystech-21 [in Russian].

Gromyko, lu.V. (2007). Chto takoe klastery i kak ikh sozdavat' [What are the Clusters and How to Create Them]. Al'manakh "Vostok" Almanac "Vostok", 1(42). Retrieved from: http://www.situation.ru/app/j_art 1178.htm [in Russian].

Klepikova, N.I. (2013). Otsenka effektivnosti sozdaniia otraslevogo klastera [Evaluation of the Efficiency of Creation of an Industryspecific Cluster]. Fundamental'nye issledovaniia - Fundamental Researches, 4-4, 934-939 [in Russian].

Marceau, J. (1999). The Disappearing Trick: Clusters in the Australian Economy. OECD, Boosting Innovation: The Cluster Approach (pp. 155-175). Paris.

Markusen, A. Sticky places in Slippery Space: a Typology of Industrial Districts. Economic Geography, 72(3), $293-313$.

Mesarovich, M., \& Takakhara, la. (1978). Obshchaia teoriia sistem: matematicheskie osnovy [General Theory of Systems: Mathematical Foundations] (pp. 311). Moscow: Mir [in Russian].

Metodika rascheta osnovnykh pokazatelei i ikh sopostavitel'nogo analiza, ispol'zuemykh $\mathrm{v}$ ramkakh instrumenta informatsionnoi podderzhki generatsii i razvitiia innovatsii, obespechivaiushchikh povyshenie konkurentosposobnosti obrazovatel'nykh klasterov [The Methodology for Calculating the Main Indicators and Their Benchmarking Used in the Framework of the Instrument of Information Support for the Generation and Development of Innovations that Enhance the Competitiveness of Education Clusters]. RIA Novosti - RIA News. Retrieved from: http://vid1.rian.ru/ig/ratings/metodik_region.pdf [in Russian].

Moiseev, V.S., \& Zaidullin, S.S. (2003). Modelirovanie dinamiki konechnykh diskretnykh mnozhestv [Modeling the Dynamics of the Finite Discrete Sets]. Vestnik Kazanskogo gosudarstvennogo tekhnicheskogo universiteta im. A.N. Tupoleva - Bulletin of the A.N. Tupolev Kazan State Technical University, 4, 31-36 [in Russian].

Moskovskii fiziko-tekhnicheskii institut - The Moscow Institute of Physics and Technology. Retrieved from: http://mipt.ru/news/ vedushchie-it-kompanii-obedinilis-vokrug-mfti-v-it-klaster [in Russian].

Nauchno-obrazovatel'nyi klaster v sfere torgovli, industrii gostepriimstva, servisa i uslug Respubliki Tatarstan [The Scientific and Education Cluster in the Sphere of Trade, Hospitality Industry, and Services in the Republic of Tatarstan]. Retrieved from: http://klaster-kirgteu.ru/ [in Russian].

Navigator obrazovatel'nykh klasterov: ot shkol'nika do rabotodatelia [The Navigator of Education Clusters: from a Schoolboy to an Employer]. RIA Novosti - RIA News. Retrieved from: http://ria.ru/sn_edu/20141201/1036022920.html\#ixzz3bdI5VpTc [in Russian].

Ob"iavlenie o formirovanii perechnia pilotnykh programm razvitiia innovatsionnykh territorial'nykh klasterov [The Announcement on the Formation of the List of Pilot Programs for the Development of Innovative Regional Clusters]. The Russian Ministry of Economic Development. Retrieved from: http://www.economy.gov.ru/minec/activity/sections/innovations/politic/doc20120319_001 [in Russian].

Obrazovatel'nye klastery. Natsional'nyi fond podgotovki kadrov - Education Clusters. National Training Foundation. Retrieved from: http://edu-clusters.ru/ap_norma [in Russian].

OESD Reviews of Regional Innovation: Competitive Regional Clusters: National Policy Approaches (2007, pp. 296). Paris: OESD Publishing.

Perechen' innovatsionnykh territorial'nykh klasterov [The List of Innovative Regional Clusters]. The Russian Ministry of Economic Development. Retrieved from: http://economy.gov.ru/wps/wcm/connect/8b69c0004calebe280f1ab12ac4184fa/perechen innovacionnih_klasterov.pdf?MOD=AJPERES [in Russian].

Pon'kina, E.V., \& Lobōva, S.V. (2011). Ekonomicheskii klaster: vzgliad s pozitsii teorii sistem i sistemnogo analiza [Economic Cluster: a View from the Perspective of the Theory of Systems and System Analysis]. Izvestiia vysshikh uchebnykh zavedenii. Seriia: Ekonomika, finansy i upravlenie proizvodstvom - News of the Higher Education Institutions. Series: Economy, Finance, and Production Management, 4, 90-99 [in Russian].

Porter, M. (1993). International Competition (pp. 676). Moscow: International Relationship [Mezhdunarodnye otnoshenija].

Porter, M. (2002). Konkurentsiia [The Competition] (pp. 496). Moscow: Izdatel'skii Dom Vil'iams [in Russian].

Porter, M. (2003). Russian Competitiveness: Institute for Strategy and Competitiveness (pp. 27). Harvard Business School.

Renking mezhregional'nykh obrazovatel'nykh klasterov [Ranking of the Interregional Education Clusters]. RIA Novosti. Retrieved from: http://vid1.rian.ru/ig/ratings/klaster_11.pdf [in Russian]. 
Renking regional'nykh obrazovatel'nykh klasterov [Ranking of the Regional Education Clusters]. RIA Novosti. Retrieved from: http://vid1.rian.rulig/ratings/klaster_12.pdf [in Russian].

Renkingi obrazovatel'nykh klasterov: osnovnye rezul'taty analiza i interpretatsii poluchennykh dannykh v ramkakh aprobatsionnogo issledovaniia [Rankings of Education Clusters: the Main Results of the Analysis and Interpretation of the Data Obtained in the Framework of the Approbation Research]. RIA Novosti. Retrieved from: http://vid1.rian.ru/ig/ratings/klaster_rezalt.pdf [in Russian]. Rosenfeld, S. (1997). Bringing Business Clusters info the Mainstream Development. European Planning Studies, 5, 3-23.

The Tambov Business College. Retrieved from: http://www.tbcollege.ru/index.php?main_menu=clasterit [in Russian].

The Ural State University of Economics. Retrieved from: http://science.usue.ru/attachments/850_Kontseptsiya\%20razvitiya\%20 innovatsionno-obrazovatelnih\%20klasterov\%20S0\%20\%28Col\%29.pdf [in Russian].

Tsikhan, T.V. (2003). Cluster Theory of Economic Development. Management Theory and Practice, 5, 102.

Veblen, T. (1964). The Instinct of Workmanship and the State of Industrial Arts (pp. 355). New York. 